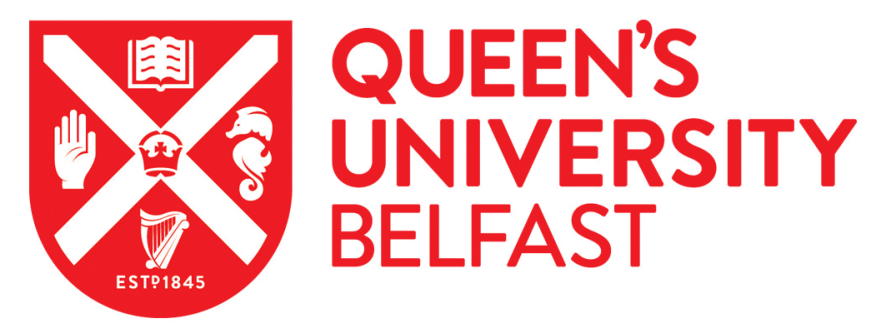

\title{
Bargaining, representation and organising in the Pandemic: Experience from the Financial Services Union
}

Cullinane, N., \& Murphy, G. (2021). Bargaining, representation and organising in the Pandemic: Experience from the Financial Services Union. International Union Rights: Journal of the International Centre for Trade Union Rights, 28(2), 20-21. https://doi.org/10.14213/inteuniorigh.28.2.0020

Published in:

International Union Rights: Journal of the International Centre for Trade Union Rights

Document Version:

Peer reviewed version

Queen's University Belfast - Research Portal:

Link to publication record in Queen's University Belfast Research Portal

Publisher rights

Copyright 2021, International Centre for Trade Union Rights

This work is made available online in accordance with the publisher's policies. Please refer to any applicable terms of use of the publisher.

\section{General rights}

Copyright for the publications made accessible via the Queen's University Belfast Research Portal is retained by the author(s) and / or other copyright owners and it is a condition of accessing these publications that users recognise and abide by the legal requirements associated with these rights.

Take down policy

The Research Portal is Queen's institutional repository that provides access to Queen's research output. Every effort has been made to ensure that content in the Research Portal does not infringe any person's rights, or applicable UK laws. If you discover content in the Research Portal that you believe breaches copyright or violates any law, please contact openaccess@qub.ac.uk. 


\section{Bargaining, representation and organising in the Pandemic: Experience from the Financial Services Union}

Gareth Murphy, Head of Industrial Relations and Campaigns, Financial Services Union

Niall Cullinane, Senior Lecturer in Employment Relations and Human Resource Management, Queen's University Belfast

The global pandemic presents many new problems to trade unionism. Social distancing and home working, for example, introduce real challenges to union organisation rooted in the physical workplace. Moreover, while online communication platforms were the natural response for many organisations, it is unclear whether the fundamentals of trade unionism - building collective identity, collective organising and collective action - are conducive to online dynamics. Unions are not known hotbeds of technological adoption. The face-to-face meeting, a word in the ear of a relevant party, collective meetings with members and - where called for - public demonstrations, are the stock-in-trade of what unions do. Union negotiators need to 'read the room', make eye contact and watch body language to be effective negotiators. Likewise, union organisers in recruiting and developing new members need to build rapport and establish trust and confidence, best achieved by face-to-face, interpersonal contact. Although societies are making meaningful advances in the return to some prepandemic normalcy in 2021 and beyond, much remains uncertain. Reliance upon online communication platforms may, by necessity, retain their importance. To that end, it is helpful to reflect on the shift to online unionism amid the pandemic, considering what worked and what did not, what to retain even if social distancing recedes and what might present ongoing obstacles to navigate where it persists. As part of this effort, we offer insights from the Financial Services Union (FSU)- one of the leading trade unions in Ireland, Northern Ireland and Great Britain for representing staff in the financial services sector with approximately 15,000 members $<w w w . f s u n i o n . o r g>$. Almost overnight in March 2020, FSU, like so many others, turned from a union based in offices and workplaces to a virtual union operating online and remotely. Below we look at how FSU dealt with the challenge of shifting operations 
online and reflect on the experience of bargaining, engaging the membership and organising new members.

\section{Becoming an online union}

All trade unionists will testify 2020 brought some unique challenges for representatives and members. Ensuring that the turn to home working was mindful of childcare difficulties, supports for self-isolation, maintaining socially distant workplaces with adequate ventilation and cleaning facilities sat alongside more familiar issues like pay bargaining and job protection measures. Representatives in FSU, as elsewhere, had to tackle these issues head-on, albeit remotely, while simultaneously adjusting to a new environment of engaging with employers online via new technology. Compounding these challenges was the need to coordinate and respond to the needs of a now dispersed membership: some working from home, others on-site in highly controlled environments.

Thankfully, the union had - by pure luck- in 2019 and early 2020 upgraded its phone systems and internal software packages, including adding Microsoft Teams and installing VPN's (virtual private network) software to facilitate remote network access. Consequently, only a small number of laptops and upgrades were required to support all staff and officers working from home. There was minimal disruption to the union's day-to-day operations as a result, and the union quite quickly adapted to the technical requirements of going online.

However, having the hardware and software available does not necessarily mean everyone can and will use it. The union utilised its online education platform https://unionlink.org/ to develop Microsoft Teams training modules. Here, staff and officers worked in virtual groups to complete training modules involving individual and teamwork exercises. Notably, the prospect of remote working within FSU impelled greater urgency in taking steps to deepen staff interactions in compensation for the loss of in-person dynamics. Officers instituted more team and all-staff meetings than previously done in person in the office - which was often not possible when staff were engaged in different activities on sites or in representations with employers, civil servants or politicians. The industrial relations team began meeting twice a week, with specific communications meetings at the end of the week, while the organising team began meeting once a week. In part, the union's General Secretary drove this change, 
moving the focus away from longer-term work plans to more short-term, immediate and focussed activities and deliverables. The greater regularity of group meetings on Microsoft Teams allowed for increased information sharing, best practice outcomes and further planning of weekly activities.

\section{Bargaining with employers}

While MS Teams was the software of choice for FSU, officials faced the additional challenge of adapting to the technology of individual employers for representation and negotiation. Skype, Zoom, Cisco Webex, Google Meet all had to be learnt in different meetings ensuring officials were comfortable sharing screens, navigating virtual breakout and side meeting rooms for effective representation and negotiation. However, officials typically resorted to Whatsapp group chats to ensure private dialogue on their side was maintained during talks - the virtual equivalent of passing a note down the line!

What was the experience of using the various online platforms when engaging employers? The evidence admittedly is not favourable. The technology was inevitably stop-start at times during often crucial talks on complex and novel issues, e.g., pay protection for those self-isolating or arrangements for those working at home with childcare responsibilities. The ubiquitous "you're on mute!" alongside a range of other technical problems is not conducive to workable negotiations and constructive dialogue. Indeed, the view of some officials was that the technology added tensions and difficulties to already challenging talks. Another official feared that these interactions would end up weakening relationships with employers. As a result, there was greater reliance on phone conversations and even socially distanced face-to-face conversations in open-air locations that had to happen offside to make any meaningful progress in talks.

\section{Keeping in touch with the membership}

In engaging the membership, the pandemic looks to have intensified a more significant deployment of social media to communicate with members. With the opportunity of interaction between local representatives, activists and members curtailed, the union ramped up its embrace of Facebook and Twitter for example. The union's social media usage of Twitter increased significantly, with more than double the number of tweets from FSU in 2020 (424) compared to 2019 (160). Social media focused on articulating 
union priorities like pay protection, health and safety and halting redundancies, and updates on agreements reached with employers and advice and guidance to members. The union even directed a public message at customers to protect members' interests. Customers were reminded that where branch visits were necessary, social distancing and sanitation guidelines be followed and respect shown to front-line staff. With 724 Facebook shares, this post was the most popular union post of the period.

\section{Organising online}

FSU started 2020 with plans for organising based on physically visiting locations with information stands, activist meetings, local training, drop-in clinics and greenfield site visits. With these plans disrupted, activity turned to digital surveys/petitions and lead generation, follow-ups and activist training. The training for virtual organising was assisted by UNI Global Union and focussed on the importance of phone conversations with members. There was a significant increase too in digital surveys/petitions directed at members and non-members alike. In part, increased surveys/petitions reflected the plethora of pandemic induced work-related issues, but it also served as a substitute for more traditional means of organising.

For example, in 2019, the union completed eight digital surveys/petitions, whereas, in 2020, there were 17 surveys/petitions. These enabled non-members to add contact details which then served as leads for organisers to follow up. The union also developed on non-member leads with subsequent invitations to an 'Introduction to FSU' meeting focussed on 'live issues' prevailing in a particular employer at any given time.

How well did these activities work? We observed evidence of modest gains: 407 nonmember leads generated across the 17 surveys/petitions generated 30 new members (a conversion rate of $7 \%$ ). Notably, 13 of the 17 surveys/petitions occurred in workplaces where the union was already recognised, thus acting as a form of in-fill recruitment. With access to greenfield sites more complicated, FSU organisers undertook six survey/petitions in such locations. However, it was here that the union recruited the bulk of new members. Ultimately organisers report that the experience of organising via online platforms is challenging. The view is that individual and inperson face-to-face conversations are much more effective in converting non- 
members to membership. To this end, the union has made some rudimentary comparisons for analysis between virtual methods and targeted in-person, face-toface conversations with non-members from 2016 data. Then, with a sample of 286 non-members targeted for face-to-face conversations, a conversion rate of $36 \%$ was observed.

\section{Lessons from 2020}

The experience of online unionism amid the pandemic has been very much a mixed one. Internally, the shift to online unionism in the context of home working enhanced opportunities for officers and staff to come together to share ideas more frequently in a way that was not possible pre-pandemic. Such developments are positive. The greater embrace of social media during the pandemic opens new avenues to connect with the membership and the public, enhancing recognition of the union and its work. Yet, the experience of exchanges with employers via collective bargaining online has been less than ideal. We remain less confident that there will be an appetite for continued engagement with bargaining online when the pandemic recedes. Organising online also has limits too and seems to be an inferior method to the more traditional in-person methods for inspiring workers to join and commit to trade unionism. 